Revisiting Qumran Cave 11

Eibert Tigchelaar, KU Leuven

1. Manuscript Remains: Scrolls and Fragments

Which scrolls materials were found in Qumran Cave 11? The most recent and most comprehensive overview of the manuscript remains from Cave 11 is presented in the form of a list in Emanuel Tov's Revised Lists. 'The list gives thirty-one items, from ${ }_{11} \mathrm{Q}_{1}$ through ${ }_{11} \mathrm{Q}_{31}$. Twenty-eight of those have been fully published in DJD $23 .{ }^{2}$ The exceptions are ${ }_{11 Q 1}$ (the Paleo-Leviticus scroll), ${ }^{3}{ }_{11}{ }_{5}$ (the Great Psalms Scroll), ${ }_{4}^{4}{ }_{11}{ }_{19}$ (the Temple Scroll), ${ }^{5}$ and a few purported Cave 11 fragments which

${ }^{1} \mathrm{E}$. Tov, Revised Lists of the Texts from the Judaean Desert (Leiden: Brill, 2010) 64-78, replacing his earlier "Lists of the Texts from the Judaean Desert," in E. Tov (ed.), The Texts from the Judaean Desert: Indices and an Introduction to the Discoveries in the Judaean Desert Series (DJD 39; Oxford: Clarendon, 2002) 27-114, esp. 77-89.

${ }^{2}$ F. García Martínez, Eibert J.C. Tigchelaar, and A.S. van der Woude, Qumran Cave 11 II: "1Q2-18, 11Q20-31 (DJD 23; Oxford: Clarendon, 1998).

${ }^{3}$ D.N. Freedman and K.A. Mathews, The Paleo-Hebrew Leviticus Scroll (nQpaleoLev) (Cambridge, MA: American Schools of Oriental Research, 1985). See, in addition: E. Puech, "Notes en marge de 11QPaleeoLévitique. Le fragment L, des fragments inédits et une jarre de la grotte 11, $R B 96$ (1989) 161-83, pls. 1-3; E.J.C. Tigchelaar, "Some More Small 11Q1 Fragments," RevQ 18/70 (1997) 325-30, pl. 2. ${ }^{4}$ J.A. Sanders, The Psalms Scroll of Qumran Cave 11 (nQPs ${ }^{a}$ ) (DJD 4; Oxford: Clarendon, 1965) published the scroll and fragments A through D. Y. Yadin, "Another Fragment (E) of the Psalms Scroll from Qumran Cave $11\left(\mathrm{nQPs}^{\mathrm{a}}\right)$," Textus 5 (1966), Pls. 1-5 published the large fragment E. Sanders incorporated fragment E in his The Dead Sea Psalms Scroll (Ithaca, NY: Cornell University Press, 1967). García Martínez, Tigchelaar, and van der Woude presented a revision of fragment E, and published the tiny fragment F, in DJD 23.

${ }^{5}$ First publication by Y. Yadin, The Temple Scroll, 3 vols. (Jerusalem: Israel Exploration Society, 1977) [Hebrew], and The Temple Scroll, 3 vols. (Jerusalem: Israel Exploration Society, 1983) [English]. 
turned up since the publication of DJD $23 .{ }^{6}$ Of these thirty-one items, twenty-nine were identified as separate manuscripts, ranging from scrolls to single fragments. ${ }_{11}{ }_{30}$ "Unclassified Fragments" contains various fragments, some of which might belong to those twenty-nine manuscripts, while others may be the last remains of one or more other manuscripts. ${ }^{7}$ The material referred to as ${ }_{11} \mathrm{Q}_{31}$ "Unidentified Wads" is probably all from the same manuscript, but has only a few letters that are visible to the naked eye.

Tov's list includes eight manuscripts that were found as partially or entirely rolled up scrolls. In order of their sigla they are: ${ }_{11} \mathrm{Q}_{1}$ the Paleo-Leviticus scroll, ${ }_{11} \mathrm{Q}_{4}$ the Ezekiel scroll, ${ }_{11} \mathrm{Q}_{5}$ the Great Psalms Scroll, 11 Q10 the Job Targum scroll, 11 Q11 the Apocryphal Psalms scroll, ${ }_{11}{ }_{17}$ the Shirot Olat ha-Shabbat scroll, 11 Q18 the New Jerusalem scroll, and, finally, ${ }_{11} 19$ the Temple Scroll. There are photographs of all those scrolls in their unopened condition, ${ }^{8}$ with the exception, to my knowledge, of ${ }_{11 Q 1} .^{9}$ Six of the scrolls were sold through Khalil Iskander Shahin (Kando) to the Palestine Archaeological Museum; a seventh, 11Q11, was recovered during de Vaux's excavations of Cave 11 in March 1956; $;^{10}$ the eighth, the Temple Scroll, was seized from Shahin during the Six-Day

${ }^{6}$ In Tov, Revised Lists, those are ${ }_{11 Q}$ frags. $3 \mathrm{a}+3 \mathrm{~b} ; 11 \mathrm{Q} 12$ frag. $7 \mathrm{a} ; 11 \mathrm{Q} 16$ frag. 2.

${ }^{7}$ For example, frags. 8-10. Cf. DJD 23, p. 438 and H. Jacobson, "11Q30, Fgs. 8-10", RevQ 18/76 (1998) 595. ${ }^{8} 11 \mathrm{Q}_{4}$ on PAM $43 \cdot 731$ and 43.742, DJD 23 Pl. 54; 11Q5 on PAM 43.772-43.775, DJD 4 Pl. 1 shows 43.774; 11 Q10 on PAM 43.796-43.799 (in the middle of the photographs); 11 Q11, 11Q17, and 11 Q18 on PAM 43.981, DJD 23 Pl. 53; 11 19 Yadin, Temple Scroll Vol. 3, Pl. 4.1.

${ }^{9}$ The earliest photographs, PAM 42.171 and 42.172 , taken in July 1956, show cols. 2-3, and cols. 5 (left part) and 6 of the unrolled scroll. On these photos there is a support behind the scroll, indicating it had been unrolled and supported earlier, before photographing. The scroll had been purchased on 19 May $195^{6 .}$

${ }^{10} \mathrm{R}$. de Vaux, "Fouilles de Khirbet Qumrân. Rapport préliminaire sur les 3e, 4e et 5e campagnes" $R B$ $63\left(195^{6}\right) 533-77$, at 574 , refers to the recovery of a document in the shape of a hardened and blackened cigar (in his excavation diary he refers on $3 / 3$ / to "un petit rouleau très abîmé." This has occasionally been mistaken for a reference to the Cave 11 Ezekiel scroll (11Q4). See, e.g., W. Fields, 
War in June 1967. One should note, though, that from the first years after the discovery of Cave 11 onwards, there have been reports about more scrolls. In his description of the Cave 11 finds, Lankester Harding already referred to "rumours of other good scrolls from the same cave" and "reports of two nearly complete copies of the Book of Daniel among these."11 Joseph Uhrig, or Mr. Z., the middleman between Shahin and Yadin, provided lists of Cave 11 scrolls for sale that outnumber the ones we know now. Those lists may be seen as unreliable, but even the official second agreement signed 12 December, 1962, between the Palestine Archaeological Museum and the Dutch Royal Academy of Arts and Sciences mentions a higher number of scrolls than eventually were acquired. Either all those accounts were fabricated or exaggerated, or there actually were one or more small scrolls, that now are unknown to us.

The Dead Sea Scrolls: A Full History Volume 1, 1947-196o (Leiden: Brill, 2009) 299. However, the unopened ${ }_{11} \mathrm{Q}_{4}$ scroll does not look at all like a cigar, while the unopened ${ }_{11} \mathrm{Q}_{11}$ scroll immediately reminds one of a bolknak type of cigar (see the left scroll on PAM 43.981). See also J.P.M. van der Ploeg, "Lédition des manuscrits de la Grotte XI de Qumrân par l'Académie Royale des Sciences des Pays-Bas," in P.W. Pestman (ed.), Acta Orientalia Neerlandica: Proceedings of the Congress of the Dutch Oriental Society Held in Leiden on the Occasion of its 5oth Anniversary, 8th-gth May 1970 (Leiden: Brill, 1971) 43-45 at 44 who states: "Parmi les rouleaux découverts dans la grotte XI, nous avons trouvé un petit rouleau fort endommagé qui avait la forme d'un petit cigare trapu. Il contient des psaumes apocryphes."

"'Notes and News," Palestine Exploration Quarterly 89 (1957) 93-96, at 95. Cf. in largely the same words also G. Lankaster Harding, "Recent Discoveries in Jordan," Palestine Exploration Quarterly 90 (1958) 7-18, at 17, but without the reference to Daniel. Rumours on the existence of additional Cave 11 scrolls, especially of either Daniel or Enoch scrolls, persist to the present day. See, for example, the interview with John Strugnell in the Biblical Archaeology Review (July/August 1994), in which he also states that he “wouldn't be surprised if there were five other manuscripts from Cave 11 sometime to be found in the near future." 
The publication rights of the three "biblical" scrolls were all sold to American institutions, the American Schools of Oriental Research and the Claremont Graduate School. The publication rights of the Job Targum were acquired by the Dutch Royal Academy of Arts and Sciences and the Organisation of Scientific Research on 11 December 1961. One year later the publication rights of the remnant of the other Cave 11 manuscripts, that is, the other scrolls (except 11Q1) and fragments, were also acquired by the Dutch institutions. ${ }^{12}$ The Temple Scroll came into Israeli hands in 1967.

Most of the materials had been found by the Bedouin, and were sold in two stages to the Palestine Archaeological Museum, namely on May 19 and July 17, 1956. According to de Vaux's short notes, a few parchment fragments, including some written in paleo-Hebrew, as well as a cigar-like scroll were found during the excavation. Whereas the cigar-like scroll (11Q11) apparently was added to the Cave 11 collection purchased from the Bedouin, there was no clarity about the identity or whereabouts of the excavated fragments. It was assumed these were incorporated into the Museum collection, ${ }^{13}$ but Mireille Belis discovered Cave 11 fragments among the Cave 11 textiles at the Ecole biblique et archéologique, which have been published now by Emile Puech. ${ }^{14}$ However,

${ }^{12}$ The agreement of December 12, 1962 lists them as follows:

a. Unopened scroll and fragments containing aramaic text about the New Jerusalem;

b. Unopened scroll and fragments containing a text provisionally denoted "Olat ha-Shabbat"

c. Numerous fragments containing biblical texts in square Hebrew (Leviticus, Deuteronomium, Psalms) and non-biblical texts

d. Two unopened scrolls of unknown content

e. Some small scrolls and fragments also found in Cave 11

${ }^{13}$ See, for example, Sanders, Dead Sea Psalms Scroll, 6: “On November 20 [1961], Father de Vaux ... asked Mr. Saad to bring the loose fragments from Cave 11, some of which had been purchased with the $\left[11 Q_{5}\right]$ scroll and some of which had been recovered when the archaeologists subsequently excavated the cave."

${ }^{14}$ See, in this volume, E. Puech, "Nouveaux menus fragments de la grotte XI", and M. Fidanzio, "Note: the Finding of Unknown Manuscript Fragments from Cave 11." 
also after the $195^{6}$ purchase of Cave 11 materials from Shahin and the archaeological excavation by de Vaux, other fragments have turned up, which, without any doubt, could be assigned to the Cave 11 manuscripts. This indicates that not all the materials found by the Bedouin had been sold through or by Shahin in 1956 to the Palestine Archaeological Museum. This seems to be confirmed by Frank Cross's report of Cave 11 fragments that were shown to him in Beirut in $1967 .^{15}$

Most famous of the fragments that turned up later are the large fragment $\mathrm{E}$ of the Psalms Scroll, which was sold, through Joseph Uhrig, to Yigael Yadin in 1960 and the large fragment L of the Paleo-Leviticus scroll which was sold (apparently in 1967) to Georges Roux. One of the 11 Q10 fragments which was presumably seized from Shahin in 1967 , was brought to the Shrine of the Book, and eventually identified in 1992 and published in $1993 .{ }^{16}$ Another example is the Vatican Paleo-Hebrew fragment, bought by Salvatore Garofalo, perhaps already in the 1950s, which should be assigned to ${ }_{11} \mathrm{Q}_{22}{ }^{17}$ In the case of the Temple Scroll, two fragments from subsequent layers of the scroll were broken off from the scroll. Uhrig reports that he himself broke off, late 1960 or early 1961, one fragment from the scroll, which he sent to Yadin as a sample of the scroll that was for sale

${ }^{15}$ F.M. Cross, "Reminiscences of the Early Days in the Discovery and Study of the Dead Sea Scrolls," in L.H. Schiffman/E. Tov/J.C. VanderKam (ed.), The Dead Sea Scrolls Fifty years After Their Discovery: Proceedings of the Jerusalem Congress, July 20-25, 1997 (Jerusalem: Israel Exploration Society, 2000) 932-43, at 941-42. It remains unclear whether Cross recognized the fragments as Cave 11 fragments, or simple assumed they were from Cave 11, or whether their provenance was told to him.

${ }^{16}$ B. Zuckerman with S.A. Reed, "A Fragment of an Unstudied Column of 11QtgJob: A Preliminary Report," The Comprehensive Aramaic Lexicon 10 (1993) 1-7. One may note that the first photographs of the ${ }_{11}$ 10 materials in PAM 43.796-799 show piles of the 11 Q1o fragments, in complete disorder, indicating that a fragment might easily have been kept apart.

${ }^{17}$ G. Lacerenza, “Un nouveau fragment en écriture paléohébraïque," $\operatorname{Rev} Q 19 / 75$ (2000) 441-47, E. Puech, "Note additionelle sur le fragment en paléo-hébreu," ibid., 449-51. 
(this fragment is from col. XV). ${ }^{18}$ The other fragment (from col. XIV) ended up in the collection of Arnold Spaer, and was published by André Lemaire. ${ }^{19}$ This raises the question whether there are still more Cave 11 fragments that were not sold to the Museum or seized in 1967.

Tov's list reports of a series of such fragments potentially from Cave 11. One such fragment, found in the desk of Yadin, was published in DJD 23 as 11Q8 frag. $3 \cdot{ }^{20}$ Two other fragments from Yadin's desk drawer are listed twice in Tov's list, namely both as XQ5a and $5 \mathrm{~b}$ with the sigla they received in DJD 36, and as ${ }_{11 Q 12}(11 \mathrm{QJub}) 7 \mathrm{a}$ resp. ${ }_{11 Q 16}\left(11 \mathrm{QHymns} \mathrm{s}^{\mathrm{b}}\right)$ 2, the identification proposed by Hanan Eshel. The 11Q8 identification is plausible but not certain. Eshel's two other identifications are clearly erroneous, both textually and palaeographically. ${ }^{21}$ Nonetheless, some of the unpublished small fragments from the same plate (IAA \# $\left.\mathrm{X}_{7} 8-\mathrm{X}_{79}\right)$ can plausibly be assigned to $11 \mathrm{Q}_{20}$. It remains a question how Yadin got hold of these fragments and where they are from. It is easiest to assume that these fragments originate from the Shahin collection. One remote possibility is that at the same time when the Temple Scroll and the Job Targum were seized from Shahin, also those smaller fragments were confiscated. But then, why were they not brought to the Shrine of the Book? It is more likely that Yadin purchased them, just as he also acquired Bar Kokhba period documents from Shahin. ${ }^{22}$ If the Yadin Hebrew and Aramaic fragments on IAA X 78 -X79 and X8o came from Shahin, there would be no need to assume they all came from the same cave. In sum, the two Yadin fragments XQ5a and 5b, which were identified by Hanan Eshel as ${ }_{11 Q 12}$ and 11Q16, could ei-

\footnotetext{
${ }^{18}$ See the fragment depicted in Yadin, Temple Scroll, vol. 3 Pl. 3·3-4.

${ }^{19}$ A. Lemaire, "Nouveaux fragments du Rouleau du Temple de Qumrân," RevQ 17/65-68 (1996) 271-74. ${ }^{20}$ S.A. Reed, The Dead Sea Scrolls Catalogue: Documents, Photographs and Museum Inventory Numbers (Atlanta: SBL, 1994), 185, 460 referred to this fragment as "Masıg." and later the fragment was referred to as "XQPs". These old sigla are still mentioned in Tov, Revised Lists, 70.

${ }^{214}$ E. Tigchelaar, "Notes on the Three Qumran-Type Yadin Fragments Leading to a Discussion of Identification, Attribution, Provenance, and Names," DSD 19 (2012) 198-214.

${ }^{22}$ See, briefly, H. Eshel, “Gleaning of Scrolls from the Judean Desert," in C. Hempel (ed.), The Dead Sea Scrolls: Texts and Context (Leiden: Brill, 2010) 49-87, at 78-79.
} 
ther come from Cave 11, in which case they would represent two additional manuscripts from this cave, or from another findplace, such as Qumran Cave 4.

Tov's list of Cave 11 items also contains other questionable references. The list mentions two fragments, one from the Ashland Theological Library and the other presently belonging to The Museum of the Bible, which Hanan and Esther Eshel identified as ${ }_{11} Q_{7}$ frags. $3 \mathrm{a}^{-} \mathrm{b}^{23}$ The Museum of the Bible fragment has recently been published, and the style of the hand is clearly different from ${ }_{11} Q_{7}$, so that there is no reason to assign the fragment to Cave $11 .{ }^{24}$ It is not even certain the fragment is authentic. ${ }^{25}$ Tov's list also includes references to Schøyen 5095/1 as preserving fragments from ${ }_{11 Q T}$ cols. 2 and 3. Schøyen himself quotes a signed statement of William Kando, claiming that these fragments were found in the same jar in which the Temple Scroll was found, and were presented in 1961 to a customer in Zurich. ${ }^{26}$ The editors, Torleif Elgvin and Kipp Davis, describe Schøyen 5095/1 as "Wads from 11QTa , Unidentified Fragments from Cave 11" and argue that at least one of the wads (Wad Z) has several correspondences with ${ }_{11 Q T} \mathrm{~T}^{\mathrm{a}}$, so that it might stem from

${ }^{23}$ E. Eshel and H. Eshel, "A Preliminary Report on Seven New Fragments from Qumran," Meghillot 5-6 (2007) 271-78 at 276-77; Eshel, "Gleaning of Scrolls," 74.

${ }^{24}$ L.M. Wolfe et al., "Psalm 11:1-4 (Inv. MOTB.SCR.ooo121)," in E. Tov/K. Davis/R. Duke (ed.), Dead Sea Scrolls Fragments in the Museum Collection (Leiden: Brill, 2016) 190-99.

${ }^{25}$ Most of the fragments acquired after 2002 by private collectors are most probably forgeries. See E. Tigchelaar, "A Provisional List of Unprovenanced, Twenty-First Century, Dead Sea Scrolls-like Fragments," DSD 24 (2017): 173-88; K. Davis et al., "Nine Dubious 'Dead Sea Scrolls' Fragments from the Twenty-First Century," DSD 24 (2017) 189-228; K. Davis, "Caves of Dispute: Patterns of Correspondence and Suspicion in the Post-2002 "Dead Sea Scrolls" Fragments," DSD 24 (2017) 229-70.

${ }^{26}$ M. Schøyen, "Acquisition and Ownership History: A Personal Reflection," in T. Elgvin/K. Davis/M. Langlois, Gleanings from the Caves: Dead Sea Scrolls and Artefacts from The Schøyen Collection (London: Bloomsbury T\&T Clark, 2016) 25-31 at 29. 
the beginning of the Temple Scroll. ${ }^{27}$ The claim is largely based on the analysis of the wrappings which were unified with a wad. ${ }^{28}$

On the basis of physical research which showed the presence of magnesium ammonium phosphate, or struvite, which is specifically associated with bat and seebird guano, Elgvin also tentatively assigns Schøyen 4612/3, which Puech had earlier published as 4Q587 4QTestament ${ }^{\mathrm{d}}{ }^{29}$ to Cave 11, and calls it ${ }_{11} \mathrm{Q}\left(\right.$ ?)Eschatological Fragment. ${ }^{30}$ On palaeographic and visual grounds, Puech identified the Schøyen fragment and a fragment published by Lemaire (from the Spaer collection $)^{31}$ as coming from the same manuscript. It is tempting to associate these two small Aramaic fragments, ${ }^{32}$ but Esther Eshel correctly observed that the fragments have different ways of writing the mem. ${ }^{33}$ We should be cautious with respect to all those recent identifications. Some identifications are patently wrong, and it certainly would have been best not to include these fragments in the official lists as either Cave 11 or Cave 4 fragments.

${ }^{27}$ T. Elgvin and K. Davis, "MS 5095/1, MS 5095/4. Wads from 11QT', Unidentified Fragments from Cave 11, in Elgvin et al., Gleanings, 301-8, at 302.

${ }^{28}$ On these claims, see more specifically my review of Gleanings in RevQ 29/110 (2017).

${ }^{29}$ E. Puech, Textes araméens: Deuxième partie (DJD 37; Oxford: Clarendon, 2009) 501-4.

${ }^{30} \mathrm{~T}$. Elgvin, "Texts and Artefacts from the Judaean desert in The Schøyen Collection: An Overview," in Elgvin et al., Gleanings, 51-6o at 53-54; E. Eshel, "MS 4612/3. 11Q(?)Eschatological Fragment ar," in Gleanings, 295-98.

${ }^{31}$ A. Lemaire, “Un fragment araméen inédit de Qumrân," RevQ 18/70 (1997) 331-33; Lemaire, "XQ6. XQOffering ar," in Qumran Cave 4.XXVI Cryptic Texts and Miscellanea (DJD 36; Oxford: Clarendon, 2000) 490-91.

${ }^{32}$ Puech stated that both fragments have the same kind of whitish spots on the surface. It could easily be tested whether those white spots on both fragments are struvite. But even then, this would not be conclusive.

${ }^{33}$ In most documents there is evidence of variation in the writing of letters, but here we are dealing with two different forms of the head and diagonal of mem. 
However, even DJD 23 contains incorrect assignments. A clearly mistaken identification in DJD 23 is my own. I assumed that the object on PAM 44.012 came from Cave $11,{ }^{34}$ and preserved the offprint (in mirror) of part of a Cave 11 manuscript. Since the preserved words correspond to Ps 6, I associated the offprint with ${ }_{11 Q}$. Hanan Eshel pointed out that the photographed object, which up to date has not been located, was probably a marl object, and hence incompatible with Cave 11, and that the hand of the writing was not similar to $11 \mathrm{Q} 8 .{ }^{35}$

It seems to me that of all the fragments published after DJD 23, only one fragment can with certainty be assigned to Cave 11, namely the Paleo-Hebrew fragment in the Vatican library (formerly Garofalo) as belonging to 11 Q22. All other post-DJD 23 associations of fragments with Cave 11 are either based on incorrect identifications with Cave 11 manuscripts or on insufficient evidence. There are, however, three or four collections of hitherto unpublished tiny Cave 11 manuscripts. First, there are the many boxes with small fragments at the Israel Antiquities Authority. Stephen Reed catalogued them in the early 1990s; I went through twelve boxes in December 1996, and got permission to select from those boxes the most important ones which I wanted to have photographed..$^{6}$ Most recently, the Israel Antiquities Authority conducted a pilot study, and Oren Ableman has been able to identify a series of fragments. ${ }^{37}$ Second, what seem to be Qumran Cave 11 fragments from the 1956 de Vaux excavation have recently turned up at the École Biblique et

${ }^{34} \mathrm{PAM} 43.975-44.011$ as well as 44.013 are photographs of Cave 11 manuscripts, which suggests that PAM 44.012 would also be related to Cave 11.. S.A. Reed, The Dead Sea Scrolls Catalogue: Documents, Photographs and Museum Inventory Numbers (Atlanta: Scholars Press, 1994) 394 described the photographed object as "11Q? One frg; seemingly reverse image on stone or plaster."

${ }^{35} \mathrm{H}$. Eshel, “A Note on 11QPs ${ }^{\mathrm{d}}$ Fragment 1," RevQ 23/92 (2008) 529-31.

${ }^{36}$ I reported on those boxes in Tigchelaar, "Some More Small 11Q1 Fragments", 326-27, n. 5, and in DJD 23, p. 438. For another IAA box found by Mauro Rottoli with-purportedly-Cave 11 fragments see Fidanzio, "Finding."

${ }^{37}$ See, in this volume, O. Ableman, "Preliminary Publication of Cave 11 Fragments from Box 1032A." 
Archéologique and are now published in this volume. ${ }^{38}$ Third, many tiny fragments of the Temple Scroll at the Shrine of the Book have not been published. This holds true for a few of the fragments from the cigar-box which was photographed in $1967 .{ }^{39}$ Some of those fragments, as well as other ones which have broken off from the scroll, in total about fifty unpublished small to minute fragments, have been placed on a museum plate with the tag "LXX (15)" which was photographed in the late $2000 .^{40}$ Fourth, the IAA plate $\mathrm{X}_{7} 8$ - $\mathrm{X}_{79}$ contains two of the three so-called Yadin fragments, but also nine small to minute fragments, some of which plausibly come from Qumran Cave $11 .^{41}$

\section{Major Publications}

2.1. The 1965 DJD 4 edition by James A. Sanders of the large Cave 11 Psalms Scroll (11Q5) suffered from the absence of the large frag. E, which was published by Yadin in 1966, and republished in DJD $23 .{ }^{42}$ Also, the edition could not take into account either the then not yet published parallel manuscript 11Q6, or the Cave 4 Psalms scrolls. No published edition has images of both the DJD 4 materials and the Yadin frag. E. Only a few editions of ${ }_{11 Q P s}{ }^{a}$ transcribe the full text of the manuscript. ${ }^{43}$ Newer photographs sometimes allow one to improve on the readings. For example, a new photo shows more clearly the first two lines of frag. D, which were ignored by Sanders, Dahmen and Ulrich. Thus, in the line above line 1 of the edition read

\footnotetext{
${ }^{38}$ See Puech, "Nouveaux menus fragments."

${ }^{39}$ Yadin, Temple Scroll, vol. 3 Pl. 3.2. See also the photograph SHR 6314.

${ }^{40}$ See section 4 below.

${ }^{41}$ See section 5 below.

${ }^{42}$ See above note 4 .

${ }^{43}$ U. Dahmen, Psalmen- und Psalter-Rezeption im Frühjudentum: Rekonstruktion, Textbestand, Struktur und Pragmatik der Psalmenrolle ${ }_{11 Q P s^{a}}$ aus Qumran (Leiden: Brill, 2003); E. Ulrich, The Biblical Qumran Scrolls: Transcriptions and Textual Variants (Leiden: Brill, 2010) 694-726.

${ }^{44}$ See http://www.deadseascrolls.org.il/explore-the-archive/image/B-367150. The presence of traces
} 
reconstruction of the scroll remains debated, both with respect to the question whether the scroll began with Ps 101, and with respect to the amount of missing columns (and their content) before and after frag. D. ${ }^{45}$

2.2. The 1977 three-volume Israel Exploration Society edition by Yigael Yadin of the large Temple Scroll, generally believed to stem from Cave $11\left(11 \mathrm{QT}^{\mathrm{a}}\right.$ or 11Q19) was a true tour de force, if only because of the detrimental state of the scroll. ${ }^{46}$ The 1983 English edition already contained many improvements, and Elisha Qimron's subsequent transcriptions of 1996 and 2010, based on extensive study of different sets of photographs and of the original, and on the parallel texts from other manuscripts, provided a great advance. ${ }^{47} \mathrm{~A}$ new full edition will be published by Lawrence Schiffman and Andrew Gross. There are still minor unpublished fragments at the Shrine of the Book which have broken from the scroll, and the old photographs frequently show small pieces with text that is not included in the editions. It is debatable, however, whether one should transcribe such minute fragments or small amount of letters without any context.

2.3. The 1985 ASOR edition of the Paleo-Hebrew Leviticus Scroll $\left(111_{1}\right)^{48}$ by David Noel Freedman and K.A. Mathews suffered from many shortcomings. Only at a late stage in the publication of the

in the top two lines was already suggested in DJD 23, p. 31, and E. Puech, "Review of Ulrich Dahmen, Psalmen- und Psalter-Rezeption," RevQ 22/86 (2005) 279-81 at 280 tentatively suggested, on the basis of less legible photographs ירע ול נפש[.

${ }^{45}$ See most recently, E. Jain, Psalmen oder Psalter? Materialle Rekonstruktion und inhaltliche Untersuchung der Psalmenhandschriften aus der Wüste Juda (Leiden: Brill, 2014) 159-77 (with survey of previous scholarship).

${ }^{46}$ See above note 5 .

${ }^{47}$ E. Qimron, The Temple Scroll: A Critical Edition with Extensive Reconstructions; Bibliography by F. García Martínez (Beer Sheva: Ben Gurion University of the Negev Press; Jerusalem: Israel Exploration Society: 1996); thoroughly revised in Qimron, The Dead Sea Scrolls: The Hebrew Writings Volume One (Jerusalem: Yad Ben Zvi Press, 2010).

${ }^{48}$ See above note 3 . 
volume the editors became aware of another major fragment at the Rockefeller Museum and of the private fragment of Georges Roux, which they could only study from a dark photograph. They also ignored the many small fragments at the Rockefeller that had broken off from the scroll. Puech's article presents many improvements on the transcriptions of the 1985 ASOR edition, and became an indispensable companion. The paleographical study by R.S. Hanson was done in 1977, and the volume does not engage the more advanced approach and the dates of McLean. ${ }^{49}$ The edition gives a long and programmatic proposal of four different orthographical systems to be found in the scrolls, but it does not discuss the textual affiliation of the scroll, and could not yet relate the scroll to the other Leviticus materials from Qumran. Ulrich's The Biblical Qumran Scrolls now presents a transcription which incorporates Puech's readings and proposals, ${ }^{50}$ but we still have no plates with all the fragments, nor an up-to-date full analysis of the text.

2.4. The 1998 DJD edition was based on many earlier editions by J. van der Ploeg, A.S. van der Woude, and Florentino García Martínez. It includes the Dutch materials as well as the few fragments that could be broken off from the Ezekiel scroll (edited by Ted Herbert) and the ${ }_{11} Q_{5}$ fragment E. The DJD edition was prepared by me in collaboration with García Martínez. In this edition, most attention was payed to matters of identification and reading of fragments, and possible reconstruction of manuscripts, and less to matters of content and the commentary. Looking back, twenty years later, I see a range of shortcomings and areas of improvement, of which I will only mention a few.

a. In some cases fragments may have been assigned to the wrong manuscript. This certainly goes for $11 \mathrm{Q} 8$ frag. 1 , and perhaps for ${ }_{11 Q} 8$ frag. $3 \cdot{ }^{51}$ Over the years I have never been entirely con-

\footnotetext{
${ }^{49}$ M.D. McLean, The Use and Development of Palaeo-Hebrew in the Hellenistic and Roman Periods (PhD diss., Harvard University, 1982). Note that Hanson dated the hand of the scroll to around 100 BCE as opposed to McLean ca. 1-50 CE!

${ }^{50}$ Ulrich's transcription based on Puech's work is reproduced in R.A. Kugler and K.S. Baek, Leviticus at Qumran: text and Interpretation (Leiden: Brill, 2017).
}

${ }^{51}$ Since both fragments were added at a very last stage in the drafts, we overlooked a number of 
fident about our assignment of 11Q6 frag. $1 .^{52}$ Originally van der Ploeg assigned this fragment, with remnants of Ps 77:18-18:21, probably on material grounds to $11 \mathrm{Q} 7{ }^{53}$ but I reassigned it to $11 \mathrm{Q} 6$ because paleographically the hand of the fragment did not fit well with $11 Q_{7}$, and looked more like that of ${ }_{11 Q 6}$. However, the execution of the letters in ${ }_{11 Q} 6$ frag. 1 is not always identical to the usual execution in the other ${ }_{11 Q 6}$ fragments, and the material differences indicate that other scenarios are possible, such as 11Q6 frag. 1 being the single preserved fragment of yet another Psalms scroll, or belonging to the ${ }_{11} \mathrm{Q}_{7}$ written by two different hands. This issue is more important than it would seem. The other fragments of ${ }_{11 Q 6}$ attest to the same Psalter collection we find in ${ }_{11} \mathrm{Q}_{5}$ which according to most scholars started with Ps 101. 11Q6 would then indicate that this form of the Psalter could also comprise earlier parts of the Psalter. However, given the multiple alternative possible assignments of ${ }_{11 Q 6}$ frag. 1, its assignment in DJD 23 cannot be used as hard data in discussions about the psalters.

b. In some cases the placement of fragments is questionable. For example, the placement of 11 Q10 frag. A6 in ${ }_{11 Q 10}$ col. XVII, and of ${ }_{11}{ }_{17}$ frag. 18 in ${ }_{11} Q_{17}$ col. VII do not agree with the damage patterns of those scrolls. Also (see below), the tentative reconstruction of 11 Q20 can be improved.

c. There are several misreadings of the Hebrew letters, and the new IAA photographs often enable better readings. In 11Q11 V 8 read, with Qimron, הצْבْא rather than הצْבْה of the DJD edition..4

errors in the transcription. In the reconstruction in frag. 1 line 1 the tetragrammaton was omitted. In frag. 3 line the word עם was omitted from the transcription, and in line 3 read תאיר rather than האיר.

${ }^{52}$ See also Jain, Psalmen oder Psalter? 181.

53J.P.M. van der Ploeg, "Fragments de Psaumes de Qumrân," in Z.J. Kapera (ed.), Intertestamental essays in Honour of Józef Tadeusz Milik (Kraków: Enigma, 1992), 233-37.

${ }^{54}$ E. Qimron, The Dead Sea Scrolls: The Hebrew Writings Volume Two (Jerusalem: Yad Ben Zvi, 2013) 346. Not all of of Qimron's corrections should be followed. E.g., in ${ }_{11} Q_{13}$ III 7 palaeographically 1] יתממ of DJD should be preferred above Qimron's correction יתמו which grammatically would be 
In 11Q15 we simply followed van der Ploeg in reading בחדריכה, which should be read, as indicated

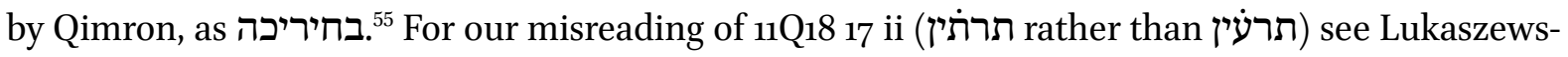
ki. ${ }^{56}$ In ${ }_{11 Q} 22$ frag. 6 read חרפותי rather than many other cases the new IAA photographs make it much easier to read the writing on the fragments, which enables us to either confirm the DJD readings or to improve on them. ${ }^{57}$ With the help of the new IAA photograph B-483154, the entire fragment $11 \mathrm{Q}_{24}$ should be retranscribed.

d. Andrew Gross has gone over all the ${ }_{11 Q} 20$ fragments and the ${ }_{11} \mathrm{Q}_{20}$ reconstruction, and has discussed some of his findings with me. The new IAA photographs clearly enable better readings in a series of cases,$^{58}$ which sometimes affect the reconstruction of the columns. ${ }^{59}$

easier (Qimron, 280). Because of damage of the upper layer of the skin, many readings in this fragment are disputed.

55.P.M. van der Ploeg, "Les manuscrits de la Grotte XI de Qumrân", RevQ 12/45 (1985) 3-15 at 7; E. Qimron, The Dead Sea Scrolls: The Hebrew Writings Volume Three (Jerusalem: Yad Ben Zvi, 2015) 247. Admittedly, the yod was somewhat damaged, but we should not have considered dalet.

${ }^{56}$ A.L. Lukaszewski, “An Alternative Reading of 11 Q18 Fragment 17 (11QNew Jerusalem)," RevQ 21/82 (2003) 321-23. CHECK

${ }^{57}$ For example, DJD 23 read [ל [לْ $[$ in 11Q17 IX 9; Qimron, Hebrew Writings, 2:379 corrected this to [לאכי][, but the piece with the mem IAA photograph B-365378 clearly reads having broken off between 1961 and 2013. Overall, I consider most of Qimron's improvements on the reading of ${ }_{11} \mathrm{Q}_{17} \mathrm{IX}$ as problematic, but, in contrast, all his corrections to the reading of col. $\mathrm{X}$ as justified.

${ }^{58}$ For example, several letters of 11 Q2o frag. 6 a which were faded away on the old infrared PAM photographs are clearly visible on the new IAA photograph, B-365328.

${ }^{59}$ For example, the rearrangement of frag. 25 vis-à-vis frag. 21 ii, on the basis of supralinear writing found on both fragments and detected by Andrew Gross. For the reading of the top line of frag. 21 ii (11Q20 XIII 3) which DJD read as וה|האים, one has to interpret the traces before not as a vertical line, but as two zayins, one on top of the other. The scribe originally wrote באים, and added before 
e. When preparing the DJD 23 edition, three of the $11 \mathrm{Q}_{22}$ (11QpaleoUnidentified text) fragments could not be located. In the mean time, all but one have resurfaced, and the new IAA photographs show the use of red ink..$^{60}$ The Vatican Paleo-Hebrew fragment should also be assigned to this manuscript, as well as some of the tiny fragments rediscovered at the École biblique et archéologique. All of this necessitates a new edition of ${ }_{11}$ 22. In this volume, Puech gives new transcriptions of most $11 \mathrm{Q}_{22}$ fragments, but not of the Vatican one. ${ }^{61}$

f. Like many editors in the DJD series, we were too dependent on Cross's paleography in two respects. First practically, by comparing letters of manuscripts with the few lines in Cross's figures, and second methodologically by accepting his typological dating. ${ }^{62}$

3. The Cave Collection as a Whole and Its Interpretation

What can we say about the collection of Cave 11 as a whole and its relation to the collections from the other caves? There may have been more manuscripts in Cave 11 than have been preserved. One therefore should be careful with claims based on the absence of specific manuscripts. We can therefore only say something on the basis of what we have now. I am very reluctant to identify

this word the letters והז, but apparently considered the cramped zayin as unclear, and therefore once again wrote the letter zayin above the earlier one. (A similar kind of supralinearly explicating a reading is found repeatedly in $\left.1 \mathrm{QIs}^{\mathrm{a}}\right)$.

${ }^{60}$ Observed both by E. Puech (forthcoming) and A. Perrot. See on the red ink in frag. 6: A. Perrot, D. Stoekl Ben Ezra, and E. Tigchelaar, "More Red Ink on the Qumran Manuscript 11Q22," Comparative Oriental Manuscript Studies Bulletin 1/1 (2015) 29-33.

${ }^{61}$ Puech, "Nouveaux menus fragments."

${ }^{62}$ F.M. Cross, "The Development of the Jewish Scripts," in G.E. Wright (ed.), The Bible and the Ancient Near East: Essays in Honor of William Foxwell Albright (Garden City, NY: Doubleday, 1961), 133-202; repr. with some revisions in Leaves from an Epigrapher's Notebook": Collected Papers in Hebrew and West Semitic Palaeography and Epigraphy (Winona Lake, IN: Eisenbrauns, 2003), 3-43. 
minute fragments with literary works on the basis of correspondences of a few letters, and I therefore ignore new proposals such as Puech's one of the identification of the fragments written in the so-called Cryptic A script. ${ }^{63}$ I also ignore the Yadin and the Schøyen fragments.

\subsection{Interpretations of Cave 11: A status quaestionis}

In the proceedings of the 2014 Lugano conference on the caves of Qumran, Florentino García Martínez extensively surveyed the different observations about the different caves, including Cave 11, on which he had written previously. ${ }^{64}$ I will only briefly summarize some earlier suggestions. Hartmut Stegemann argued that all texts came from the Qumran library. The distribution over the caves was dependent on the hasty decisions takes in the few days when the Romans approached the settlement. ${ }^{6}$ Emanuel Tov claimed that fourteen of the Cave 11 manuscripts were written according to what he calls the Qumran Scribal Practice, and that four more manuscripts reflect sectarian ideas or terminology. He therefore claimed "a strong sectarian connection of the fragments from Cave 11, stronger than that of the other caves" which would suggest that "the collection of texts in Cave 11 must have come as a whole from the Qumran community itself, possibly brought from a specific location. ${ }^{\prime 66}$ García Martínez responded that the sectarian texts par excellence are hardly attested in Cave 11, and demonstrated that from a different perspective, namely distribution

\footnotetext{
${ }^{63}$ Puech, "Nouveaux menus fragments."

${ }^{64}$ F. García Martínez, "The Contents of the Manuscripts from the Caves of Qumran," in M. Fidanzio (ed.), The Caves of Qumran: Proceedings of the International Conference, Lugano 2014 (Leiden: Brill, 2017) 67-79; García Martínez, "Cave 11 in Context," in Hempel, The Dead Sea Scrolls: Texts and Context, 199-210.

${ }^{65} \mathrm{H}$. Stegemann, The Library of Qumran: On the Essenes, Qumran, John the Baptist, and Jesus (Grand Rapids, MI: Eerdmans, 1998) 61-62.

${ }^{66}$ E. Tov, "The Special Character of the Texts Found in Qumran Cave 11, in E. Chazon/D. Satran/R. Clements (ed.), Things Revealed: Studies in Early Jewish and Christian Literature in Honor of Michael E. Stone (Leiden: Brill, 2004), 187-196, at 196
} 
of manuscripts with regard to type and content, Cave 11 would be comparable to Cave 1 . He proposed that the inhabitant of Cave 11 "brought some of the holdings of the library of the Khirbet to Cave 11 for safe keeping. ${ }^{{ }^{67}}$ Daniel Stökl Ben Ezra distinguished between "old caves" and "young caves" and argued that Caves 2, 3, 5, 6 and 11 represented the library of the community of Qumran in the first century CE, whereas Caves 1 and 4 essentially contain the holdings of the library at the end of the first century BCE. ${ }^{68}$ Stephen Pfann tried to assign the collections of the individual caves to a range of different groups. He associates the contents of Cave 11 with those of Cave 3 , both of which would have been brought by Zealots to those caves. ${ }^{69}$ Unlike other scholars Joan Taylor does not connect the scrolls in the caves with hasty rescue operations during the Jewish war, but with preservation-burials of manuscripts from the libraries of Essenes from all over Judaea. In Taylor's hypothesis, the collections in Caves 1, 2, 3, 6, and 11 (that is the natural caves with indication of presence of cylindrical jars) were such burial places. ${ }^{70}$ Sidnie White Crawford ${ }^{71}$ and Mladen Popovic $^{72}$ both do connect the disposal of manuscripts in the caves with the time of distress in the

${ }^{67}$ García Martínez, "Cave 11 in Context," 208.

${ }^{68}$ D. Stoekl Ben Ezra, "Old Caves and Young Caves: A Statistical Reevaluation of a Qumran Consensus," DSD 14 (2007) 313-33.

${ }^{69}$ S. Pfann, "Reassessing the Judean Desert Caves: Libraries, Archives, Genizas and Hiding Places," BAIAS 25 (2007) 147-70, esp. 161.

${ }^{70}$ J.E. Taylor, "Buried Manuscripts and Empty Tombs: The Qumran Genizah Theory Revisited," in A.M. Maier/J. Magness/L.H. Schiffman (ed.), "Go Out and Study the Land” (Judges 18:2): Archaeological, Historical and Textual Studies in Honor of Hanan Eshel (Leiden: Brill, 2011) 269-315. ${ }^{71}$ S. White Crawford, “Qumran: Caves, Scrolls, and Buildings", in E.F. Mason (ed.), A Teacher for All Generations: Essays in Honor of James C. VanderKam (Leiden: Brill, 2012) 1:253-73; similarly White Crawford, "The Qumran Collection as a Scribal Library," in White Crawford and C. Wassen (ed.), The Dead Sea Scrolls at Qumran and the Concept of a Library (Leiden: Brill, 2016) 109-31.

${ }^{72}$ M. Popović, "Qumran as Scrolls Storehouse in Times of Crisis? A Comparative Perspective on Judaean Desert Manuscripts," JSJ 43 (2012) 551-94. 
Jewish War. White Crawford still upholds Cross's model, while Popovic emphatically allows for the possibility that the scrolls were brought from elsewhere. I will not offer a new thesis, but rather offer some comments and highlight some features.

\subsection{The Profile of Cave 11 in relation to the other Qumran Caves}

First, as with the collections from most other Qumran caves, the collection consists exclusively of literary, that is, non-documentary texts. ${ }^{73}$ In a general sense, the literary constellation of the Cave 11 collection is comparable to that of most other Caves. As spelled out by, e.g., García Martínez, Cave 11 has the same kinds of Hebrew and Aramaic texts as many other caves. Many of the identified works are also found in Cave 4 and some also in other caves, such as its biblical works, an Aramaic translation of Job, Jubilees, the Songs of the Sabbath Sacrifice, the Aramaic New Jerusalem, and the Temple Scroll. Also, Cave 11 has a few small fragments with the same kind of Cryptic A script as found in Cave 4. One may comment that those are general observations, but that we should look at the details. Many have observed the absence of copies of the Hodayot, and the Rule of the Community or the Damascus Document. However, the small fragment 11Q29 preserved a few words which indicate a penal code similar to that attested in the Rule of the Community, the Damascus Document, and in $4 \mathrm{Q}_{265}$. Compared to Cave 4, there are neither Greek texts, not calendrical fragments or sapiential texts. This may be true, but the absence of certain works or types of texts is given the small amount of Cave 11 texts hardly significant. The data of Cave 11 are too limited to draw large conclusions. The most remarkable feature would be the presence of three copies of the Temple Scroll in Cave 11 (11Q19, $\left.11 \mathrm{Q}_{20},{ }_{11} \mathrm{Q}_{21}\right)$, as against one from all the other caves (4Q524). In brief, attempts to define the specific literary or religious character of the collection, can do so only by overemphasizing one perspective and ignoring other ones.

\footnotetext{
${ }^{73}$ That is, "texts not specifically produced for a specific pragmatic purpose of daily life like legal deeds, economic receipts and lists, letters, and so forth." See H. Gzella, A Cultural History of Aramaic (Leiden: Brill, 2015) 201.
} 
The correlation of the collection of Cave 11 manuscripts with those in the other Qumran Caves holds true not only for the literary character, or for the variation of scripts, but also for orthography and scribal practices. Tov correctly observes that the scribal practices attested in most of the Cave 11 manuscripts are similar to those from the other caves, even though I disagree methodologically with his construct of a Qumran Scribal Practice..$^{74}$ Of special interest would be those cases where we may identify a scribe who penned a manuscript from Cave 11 as well as one or more from other caves.

\subsection{Scribes}

Already van der Ploeg stated that one and the same scribe copied the Cave 1 Habakkuk pesher $(1 \mathrm{QpHab})$ and ${ }_{11 \mathrm{Q} 20}{ }^{75}$ and the arguments were described in more detail in DJD 23. One may add to the DJD 23 description still other idiosyncracies which indicate we are dealing with one scribe. For example, in both manuscripts the scribe repeatedly fails to neatly join the strokes of the letters. Thus, the right arm of shin does not always reach to the left downstroke. Even more often, the final mem is not entirely closed, because at the bottom left the strokes are not joined.

Eugene Ulrich argued that one scribe was responsible for copying $1 \mathrm{Q} 11\left(1 \mathrm{QPs}{ }^{\mathrm{b}}\right), 4 \mathrm{Q} 57$ $\left(4 \mathrm{QIsa}^{\mathrm{c}}\right)$, and ${ }_{11} \mathrm{Q} 14\left({ }_{11} \mathrm{QSM}\right),{ }^{76}$ and is reported to have added to this list also $4 \mathrm{Q} 113\left({ }_{4} \mathrm{QDan}^{\mathrm{b}}\right){ }^{77}$

\footnotetext{
${ }^{74}$ See already E. Tigchelaar, "Assessing Emanuel Tov's 'Qumran Scribal Practice”, in S. Metso/H. Najman/E. Schuller (ed.) The Dead Sea Scrolls: Transmission of Traditions and Production of Texts (Leiden: Brill, 2010) 173-207.

${ }^{75}$ J. van der Ploeg, "Une halakha inédite de Qumrân", in M. Delcor (ed.), Qumran, sa piété, sa théologie et son milieu (Paris-Gembloux: Duculot, 1978) 107-13 at 107; van der Ploeg, "Manuscrits de la Grotte XI," 9. Yadin, Temple Scroll vol. 1, 20 noted the resemblance, and stated that "The two scripts undoubtedly belong to one scribal school."

${ }^{76}$ E. Ulrich, "Identification of a Scribe Active at Qumran: $1 \mathrm{QPs}^{\mathrm{b}}-4 \mathrm{QIsa}{ }^{\mathrm{c}}-11 \mathrm{QM}$, Meghillot 5-6 (2008) ${ }^{*} 201-{ }^{*} 210$.
}

${ }^{77}$ White Crawford, "Qumran Collection as a Scribal Library," 124 n. 57. For 4Q113 (4QDan ${ }^{\text {b) }}$, cf. the 
Morphologically, the formal hands of those manuscripts have much in common, but the finer pen in ${ }_{11} 14$ and smaller size of the letters in 1 Q11, make it more difficult to ascertain whether these correspondences should be assigned to the formal character, or to an individual hand.

${ }_{11 Q 18}$ is one of the many manuscripts which according to Ada Yardeni was written by one and the same proliferous Qumran scribe. ${ }^{78}$ Yardeni's approach suffers from the absence of a methodological discussion about the relation between style, type, and individual hand, and by a focus on only a few letters. Of all the manuscripts mentioned by Yardeni, the hand of ${ }_{11} \mathrm{Q}_{18}$ seems virtually identical to that of $4 \mathrm{Q} 475$ (4QRenewed Earth), and quite similar, but with some differences, to 4Q397 (4QMMT ${ }^{d}$ ), Yardeni's base example of her Qumran scribe. ${ }^{79}$

The discovery of manuscripts written by one and the same scribe in different caves, including Cave 11, strongly suggests some kind of relationship between the collections in the different Caves. However, it neither of necessity indicates that those scribes were actually copying the manuscripts at Qumran, nor requires a shared origin of the scrolls before they were deposited in the different caves. Texts copied by the same scribe could have ended up in different subcommunities of a larger movement.

3.4. Dates of the manuscripts

drawings of Cross, "Development of the Jewish Scripts," Figure 2 line 6 where the hand is described as "a developed Herodian formal script" of circa 20-50 CE, while in the text the hand of 4 QDan ${ }^{\mathrm{b}}$ is qualified as "late Herodian." One may note that Ulrich was the editor of both 4 Q57 and 4 Q113 in the DJD series, but when he edited those manuscripts he did not comment on the possibility that both were copied by the same scribe.

${ }^{78}$ Yardeni also mentions one other Cave 11 manuscript, ${ }_{11 Q 15}$, as possibly written by this scribe, but this must be one of the several typos in her list.

${ }^{79}$ See comparison between ${ }_{11} \mathrm{Q}_{18}$ and $4 \mathrm{Q}_{397}$ in DJD 23, p. 309. Note, e.g., the different writing of bet or taw, which suggest a different execution of the writing of the letters. 
The majority of the Cave 11 manuscripts are much younger than the average manuscript from Cave 1 or 4 . If one accepts Cross's palaeographic typology, all but three or four out of twenty-six manuscripts written in the "Judean script" are Herodian, the majority developed or late. It is possible that the DJD 23 editors too often have characterized the hands as "late Herodian," but most are certainly_according to Cross's dating — from the first century CE. The few manuscripts that conform to the so-called Hasmonaean type of script are ${ }_{11} Q_{13}$, for which I refer to Puech who sees it as late Hasmonaean, ${ }^{80}$ and ${ }_{11} \mathrm{Q}_{24}$ and ${ }_{11} \mathrm{Q}_{27}$, both consisting of one fragment. In DJD 23 we qualified also 11Q29, which only has a few letters, as Hasmonaean, but the keraia on the alef may contradict this proposal.

Interestingly, the paleo-Hebrew Leviticus scroll seems also the palaeographically youngest of the paleo-Hebrew scrolls from Qumran, probably to be dated between the middle of the first century BCE and the Jewish War. ${ }^{81}$ Given that the Cave 11 manuscripts are with only very few exceptions from the first century CE, one must agree with Stökl Ben Ezra that the Cave 11 materials cannot have been a random selection from the a larger collection which also included the Cave 1 and 4 manuscripts. Any further conclusions should be part of a more comprehensive hypothesis.

Appendices

4. The Cigar box and the LII Photograph Temple Scroll (11Q19) Fragments

\footnotetext{
${ }^{80} \mathrm{Cf}$. DJD 23, p. 223, which unfortunately overlooked the discussion of the palaeographic dating in E. Puech, "Notes sur le manuscrit de 11QMelkîsédeq," RevQ $12 / 48$ (1987) 483-513 at 507-8. As a modest correction of Milik, who suggested an origin in the mid-first century BCE, perhaps even 75-50 BCE, Puech argues for a late Hasmonaean date, in the mid-first century BCE or slightly later. ${ }^{81}$ According to the forthcoming work of Mathieu Richelle and Antony Perrot.
} 
4.1. Yadin, Pl. 3.2 and the photograph SHR 6314 show a series of fragments in the Karel I Elegant cigar box which was seized from Shahin. I am not aware of any systematic listing of the fragments in this cigar box. Yadin, Pl. 3.2. shows the following fragments:

(a) top left, a fragment with mainly lower margin, and the letters כוהנים, or perhaps ל־והנים. This fragment has not been published in any edition. The fragment lies on top of another fragment without any visible writing. The two fragments are separated on SHR 6314, and the fragment with לככוהנים is found, in two pieces, in the LII photograph (see below, 4.2.).

(b) below this fragment, on the left side of the plate, a fragment that has been placed in col. 13 lines 16-17 and bottom margin (cf. Yadin, vol. 3, pl. 28).

(c) below that fragment, on the left side of the plate, a larger fragment that has part of col. 18 lines 8-11 (Yadin, vol. 3, pl. 33), and, on top of this larger fragment, a small fragment which Yadin placed at the beginning of col. 197 and read as ביבות (Yadin, vol. 3, pl. 34). Comparison with Pl. 10*:3-4 and the present Shrine of the Book image casts doubt on the placement and reading of this small fragment. It seems to more likely that this fragment belongs to col. 18 line 7 . At the end one might read כול עִ כול עם which which was proposed by Qimron, who probably also identified this small fragment as belonging to col. 18 line 7 . However, in spite of the fixed phrase עפר בו על כול עם הקהל, it is difficult to read the preceding traces as.

(d) bottom of plate, the large "wad x." Note, however, that in Pl. 3.4 the sequence of the layers (with a large part of col. 13 on top of cols. 14 and 15) is exactly opposite to the sequence in Pl. 7.1 where, as one would expect, the writing of col. 15 covers that of col. 14 and of col. 13 .

(e) very middle of the plate, small fragment with parts of two lines, which has been fitted in col. 21 lines 13-14 (Pl. 36)

(f) just below that fragment a small fragment with יח ניחוח which has been joined in col. 15 line 13 .

(g) entire right side of the plate: bits and pieces of what came to be known as the "domino." Cf. Pl. 8. 
4.2. The LII Photograph ${ }^{82}$

A plate at the Shrine of the Book labelled "LII $(15)$ " was photographed by Ira Rabin in the late 200os, some of the fragments of which were used for material research. ${ }^{8_{3}}$ On the plate are almost fifty small to minute fragments, two of which were photographed in the above described cigar box while some others have broken off from the so-called "Wad X," which can be restored to their proper place in cols. 14 and $15 .{ }^{84}$

The fragment on the top of Pl. כוהנים 3.2 of the cigar box, reading perhaps לכוהנים, has broken into several parts. The letters נים are in the left column of fragments in the LII photograph, second row. The letters לכוה are in the fifth column from the left, second row. Apparently the piece with those letters was on the top of a wad, and one can also read the layer underneath it לכבש. Given the words and the bottom margin of the fragment, these two fragments can easily be fit in col. 15 line 18 and col. 14 line 18. Hence, one can now transcribe the beginning of these lines as follows:

$$
\begin{aligned}
& \text { 14:18 [ההין [לْלבש הْאחד ל[שב]עْת הْכْבْשים ולשעْ] ... } \\
& \text { 15:18 לכוהנים בריאשं[ונה] וסמכו זקני הכוהj]ים ... }
\end{aligned}
$$

Given the "LII" tag, it makes sense to also consider possible joins of the fragments in col. $5^{2}$. One certain candidate is the fragment in the middle column, second/third from the bottom, reading מש:, which fits perfectly at the beginning of col. $5^{2}$ line 3, משכית.

\footnotetext{
${ }^{82}$ Permission to include the photograph in this publication was granted by the Israel Museum, holder of the plate with the fragments, and by Dr. Ira Rabin, who took the photograph and owns the copyright.

${ }^{83}$ I. Rabin et al., "Analysis of an antique alum tawed parchment," in E. Janssen et al. (ed.), Proceedings of the Joint Interim Meeting Multidisciplinary Conservation: A Holistic View For Historic Interiors, Rome 23-26 March 2010. Available from http://www.icom-cc.org/54/document/analysisof-an\%2oantique-alum-tawed-parchment/?id=795\#.WYyoJtOGMUE.

${ }^{84}$ Therefore, Rabin's assumption that all fragments on this plate are from col. $5^{2}$ is incorrect.
} 


\section{The Yadin Fragments}

The 1992 photograph JWS 97 shows the fragment published as XQ5 $b^{85}$ The photograph JWS 98 shows six fragments, namely, at the left the still partially rolled of folded fragment which would be published as $\mathrm{XQ}_{5} \mathrm{a},{ }^{86}$ at the right the fragment which would be published as $11 \mathrm{Q} 8$ frag. 3 , and in between four hitherto unpublished tiny fragments. Those fragments are presently on the IAA Plates X8o (only the now unfolded $\mathrm{XQ}_{5} \mathrm{~b}$ fragment) and $\mathrm{X}_{7} 8-\mathrm{X}_{79}$, with the other abovementioned fragments, as well as five more minute frags.

One of the tiny fragments can easily be associated on material and palaeographical

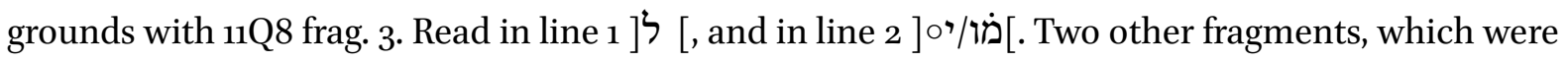
placed on top of one another in JWS 98, physically join and read as follows:

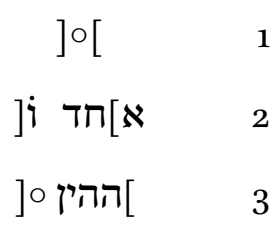

Both the hand and the remaining vocabulary strongly suggest these fragments should be assigned to ${ }_{11}$ 20. The spacing between $1 \boldsymbol{N}$ and the following is larger than a normal word-dividing space in 11 Q20.

\footnotetext{
${ }^{85}$ DJD 36, p. 487-89, incorrectly identified as ${ }^{8} \mathrm{QHymns}^{\mathrm{b}}$ frag. 2. See Tigchelaar, "Three QumranType Yadin Fragments."

${ }^{86}$ DJD 36, p. $485^{-86}$, incorrectly identified as ${ }^{11 Q J u b ~ f r a g . ~ 7 a . ~ S e e ~ i n ~ d e t a i l, ~ T i g c h e l a a r, ~ " T h r e e ~}$ Qumran-Type Yadin Fragments."
} 